\title{
Factors Influencing Career Success of Employees in Agribusiness
}

\author{
T. Macák, J. Štůsek, K. Venclová
}

Department of Management, Faculty of Economics and Management, Czech University of Life Sciences Prague, Czech Republic

\begin{abstract}
Anotace
Efektivní řízení lidských zdrojů $\mathrm{v}$ agrobyznysu může být zaměřeno na několik oblastí. Náš článek se zaměřje na faktory kariérního úspěchu $\mathrm{v}$ oblasti agrobyznysu, respektive na fundamentální nástroje řízení lidských zdrojů. Při zpracování kariérního systému je nutné navrhnou kariérní koncepce, které vytváŕí obecný rámec a zároveň determinují alternativy jednotlivých prvků kariérního systému. $\mathrm{K}$ tvorbě karierního systému jakožto předpoklad karierního růstu je nutné provést empirický výzkum a potvrdit platnost charakteristik kariérních koncepcí a jejich obsahu pro usnadnění tvorby kariérního systému. Cílem př́íspěvku je vyhodnotit souvislost mezi velikostí organizace a kariérním úspěchem zaměstnance. Dalším cílem je identifikovat faktory podílející se kariérním úspěchu. Cílevědomou kombinací funkcionálních nástrojů IT se standardními postupy dotazníkového šetření jsme dospěli logickými sekvencemi strategií pro rozhodnutí kariérního systému během návrhu průzkumu v podobě dotazníků a také při syntéze poznatků na konečnou variantu. Výsledky dotazníkových šetření byly analyzovány pomocí popisných a multidimenzionální statistických nástrojů, s využitím programů Statistica 10 a Excel 2010, podporovaných analýzou rozptylu a t-testem pro testování hypotéz. Výsledky potvrzují tři faktory pro kariérní úspěch: první je subjektivní kritérium, a sice spokojenost s kariérou. Další dva jsou objektivní faktory - profesní status a změna př́ijmů.
\end{abstract}

\section{Klíčová slova}

Informační technologie, simplex návrh, karierní úspěch, informační kompetence, informační využití.

JEL Classification: M120

\begin{abstract}
Effective HR management in the agribusiness industry can succeed in many ways. Our paper focuses to career success in the agribusiness, respectively to one of the most important human resource management tools. Applying decision-making methods using best practices in IT is cost-effective in more areas. Processing and sorting quantitative data was done using programs Statistica 10, Excel 2010. Furthermore, concerning the statistical hypothesis testing there were used modules Analysis of variance and t-test. Last but not least, there were used decision-making algorithms and corresponding software tools in support of identifying the types of suitable models of career decision-making processes.
\end{abstract}

The first part of this article concentrates on the theoretical background. The second part evaluates the results of a quantitative survey carried out for this research.

The research was conducted on a representative sample of agro-business companies, which were categorized according to EU recommendations. Representativeness of respondents' selection was achieved by the randomization of the responder sample. This sample contained information from 226 employees of the agro-business sector.

The main aim of the paper is to evaluate the correlation between organization size and employee career success. A further aim is to identify the factors involved in career success. The outcomes of the questionnaire data were analyzed using descriptive and multidimensional statistical tools, based on Statistica 10 and Excel 2010 programs, supported by analysis of scatter variance and t-test for testing hypotheses. The results confirm three factors for career success: the first is a subjective criterion, namely career satisfaction. The others are objective factors - the occupational status, and income change. With reference to these three factors it was confirmed that the size of a company has an impact on career success. It was shown that, overall, employees are happy to work with their co-workers and that they are interested in their job. They were least satisfied with the leadership. 
Purposeful combination of functionalities of IT tools with standard procedures questionnaire survey we came to the logical sequences of strategies for career decisions during the design a survey questionnaire and also in the synthesis of knowledge to the final variant.

The results further confirm that as the size of an organization increase, the number of employees who achieve a higher salary also increases. Thus, it is recommended that large organizations should utilize extrinsic career success factors, which are related to formal career programs and career plans. The next part of the research after the factor analysis (which provided us basic understanding of the significant factors to career success), was to perform more advanced methods such as Simplex Lattice Design (SLD) by adding two information technology factors (C - IT competence, D - Rate of IT utilization) to the current design.

\section{Keywords:}

Information technology, simplex lattice design, IT competence, rate of IT utilization, career success.

Macák, T., Štůsek, J. and Venclová, K. (2015) "Factors Influencing Career Success of Employees", AGRIS on-line Papers in Economics and Informatics, Vol. 7, No. 4, pp. 79 - 89, ISSN 1804-1930.

\section{Introduction}

As the European Union shifts away from agricultural subsidies schemes towards market based approaches, legislators may find agricultural producers to be reluctant to follow fixed environmental policies. The most important condition for the successful implementation of the developed solution is the input of the basic set of relevant data for the system to provide the users with expected information.

But today it is not easy to evaluate cause-effect and impact of technological, economic and social development in order to prove that IT and ICT are the factors of economic increase of efficiency, productivity and growth. Nevertheless, it can be presumed the huge progress in the field of IT and ICT are the main causes of economic changes of both commercial companies and the whole country, and these changes, first of all, are expressed by the growth of labour productivity and career success (Mačiulyté-Šniukiené, Gaile-Sarkane, 2014).

According to Zhen-Wei Qiang, Pitt and Ayers (2003), there are three channels through which ICT can influence labour productivity and economics growth: 1) TFP growth in sector producing ICT; 2) Capital Deeping and 3) TFP growth through reorganization and ICT usage. According authors Zhen-Wei Qiang, Pitt \& Ayers (2003), the ICT revolution partly consist of higher productivity growth in industries producing ICT, driven by rapid technological progress. The main characteristic of this revolution is the rapidly increasing computing power of new ICT products. In particular memory chips, as "Moore's law" holds, double their computing power every 18 months.

In the last decades employees are more and more responsible for planning their career. If their career development is limited, they will consider changing to an alternative career. This approach is important because employees have the impression that their career is successful. Thus, they are in charge of their own career. Career success is one of the most important human resource management tools (Arthur et al., 1999). Career success for an individual can be seen either as real or subjectively perceived performance, resulting from the accumulation of work experience (Judge et al., 1995). Career success consists of two parts: extrinsic/objective career success and intrinsic/ subjective career success.

Extrinsic/objective career success is considered as objective, extrinsic and measurable in relation to features which are observable and measurable by others (Dries et al., 2011). Extrinsic career success is measured by such factors as "income" and "employee promotion". It is also possible to use other factors such as rise in income, increase in social status, improved promotion prospects, and the number of direct subordinates (Fietze et al., 2011). Baruch (2006) and Arthur et al. (1999) emphasize that the three most common extrinsic factors are salary, number of job changes (promotions) and occupational status. They add to this that income is the most fundamental criterion and is included in almost every research report.

There are several variations. Verbruggen (2012) uses the net monthly income (after tax etc. has been deducted) while Judge et al. (1999) use annual income. Furthermore, occupational status is also used in this type of research. The occupational status is measured by means of the social position index (Hollingshead in Judge et al., 1999). Thus the criterion "number of employee promotions" 
is redefined as "number of job position changes" (i.e. job mobility), as used for example by Colakoglu (2011).

According to Chen (2011) the intrinsic part of career success is expressed as the individual employee's subjective reaction to their own career i.e. career satisfaction (Saari \& Judge, 2004). The most commonly utilized aspect of career satisfaction or job satisfaction is satisfaction either with income or with development of skills (Heslin, 2005). Judge et al. (1999), when measuring intrinsic career success, use a five-point Likert scale, in which the following 8 statements are evaluated: occupational status; changes in income; number of job position changes; number of promotions; net monthly income; satisfaction with income; satisfaction with degree of interest in the work involved; satisfaction with co-workers; satisfaction with utilization of knowledge; skills and abilities; satisfaction with opportunities to develop ideas on job; satisfaction with management style; satisfaction with respect expressed by others; and satisfaction with job security offered.

Despite the claim by Arthur et al. (2005), Baruch (2004) and Chudzikowski (2012) that individuals manage their own career, Judge et al. (1999) emphasize that nowadays career success depends on the employer and how the employee contributes to the organization. The size of the employing organization affects the career success, because in small companies non-standard tasks may be assigned to broaden the scope of work (Schmidt, 2011). In turn, large employer organizations provide more career paths and opportunities for promotion, with formalized career structure strategies and career plans (Baruch, 2004). The main aim of this article is to identify and assess any correlation between the size of an organization and the career success of employees. A further aim is to identify the factors involved in career success.

Optimal processes for career growth should be based on logical, systematic and strategic decision-making processes. Štůsek's (2008) model of Strategic thinking presents an interesting, but simple look at the application of the decision tree when selecting a gradual strategic options using the weights of individual factors. It also provides guidance on the use of supporting software tools.

\section{Materials and methods}

As noted earlier, the first part of this article concentrates on the theoretical background. In the second part the results of a quantitative survey are evaluated. Primary data were collected using a questionnaire survey, which took place in the period from September to November 2012. Questionnaires were distributed electronically to Czech employers using the on-line server "survio.com". The questionnaires were completed by employees over 18 years old, who were not in their first employment and had made a career transition in the previous five years. The reason for the threshold of five years was that the average period in a particular role is usually less than five years (Kvapil, 2011). Indicators of objective extrinsic career success were considered to be one or more of the following: an income change; occupational status; number of job position changes; net monthly income; and number of promotions. Based on Judge et al. (1999) career satisfaction was chosen as an indicator of intrinsic career success.

Outcomes of questionnaire data were analysed using descriptive and multidimensional statistical tools based on Statistica 10 and Excel 2010, supported by analysis of scatter variance and t-test for testing hypotheses Hendl (2006). Factor analysis was used for multidimensional analysis of data methods by Principal Component Analysis (PCA), using Varimax rotation for factor extraction (Hebák et al., 2006).

The next part of the research, after the factor analysis (which provided us basic understanding of the significant factors to career success) was to perform more advanced methods such as Simplex Lattice Design (SLD) by adding two information technology factors (C - IT competence, D - Rate of IT utilization) to the current design.

\section{Results and discussion}

A total of 1350 questionnaires were distributed. Altogether 226 employee responses were received, corresponding to a response rate of $16.74 \%$. 115 employees participated in the first part, of which 38 were men. A total of 111 employees participated in the second part, of which 28 were men. As regards age, 60 employees were $18-25$ years old, 110 were $26-35,45$ were $36-45$, 8 were $46-55$, and 3 employees were $56-65$ years old. The most highly represented age group was 18 - 35 years old.

The representative sample of respondents was created by employees from the agribusiness sector. These employees were from the business of primary production and also from the processing enterprises of agricultural commodities. The companies were categorized 
according to EU recommendation, which distinguishes small, medium and large enterprises. 32 respondents were from micro organizations (with up to 10 employees), 48 respondents were from small organizations (with 11-50 employees), 68 respondents were from medium sized organizations (with $51-250$ employees) and 78 respondents were from large organizations (with over 251 employees). Employee career mobility from one job position to another took place in every direction. All types of career transition were represented by the respondents: 66 employees had been promoted up the structure of the organization; 51 employees had stayed at the same level; 51 employees had stayed in a position related to the one before, but with more responsibilities; and 58 employees had stayed at the same level but not connected to the previous position.

\section{Career success factors}

The results confirm that there are three criteria for career success. As noted above, one of them was subjective - career satisfaction; the others were objective - occupational status and income change. Factor analysis showed that these three factors had a value higher than 1 (Kaiser-Guttman rule). Factor number 1 can be considered more important, as this factor was the first found and had the strongest variance of all analysed factors - up to two or three times higher in comparison with other factors. The results of the factor analysis (Table 1) represent correlations of variables with individual factors. Factors loadings higher than 0.4 are considered to be significant (Hendl, 2006). The first factor is career satisfaction, which includes all criteria regarding satisfaction.

According to Judge et al. (1999) this proves the validity of the methods for measurement of career satisfaction. Moreover, the results confirm the interconnectedness of the criteria of the authors' survey results. After closer analysis the authors decided to replace the criterion of satisfaction with the use of knowledge, skills and abilities. Thus, this criterion contains high factor loadings for all three factors. The authors Hebák et al. (2005) and Hendl (2006) suggest that a variable should be eliminated when the variable significantly correlates to more factors. Also, the factor 1 (intrinsic career success) consists of seven career satisfaction criteria.

Extrinsic career success criteria form the second and third factors. So, the extrinsic career success factor was divided into two parts: occupational status (factor 2) and salary changes (factor 3). Factor 2 comprises of sub factors, as can be explained by data from other research. These researches are mutually independent from each other and also define objective extrinsic criteria as relatively independent. Individual authors (e.g. Restubog et al., 2011; Verbruggen, 2012) usually test two measurement scales. In addition, salary change and salary are usually independent career success criteria (Chudzikowski, 2012). Thus both extrinsic factors remain separated and are tested as two independent variables.

Factor analysis showed that the number of promotions criterion and the net monthly income criterion were not relevant. The importance of career success criteria influences the target sample because according to our current understanding (Baruch,

\begin{tabular}{|l|c|c|c|}
\hline Career success criteria & Factor 1 & Factor 2 & Factor 3 \\
\hline Occupational position category & 0.1778 & $\mathbf{0 . 6 8 0 2}$ & 0.0220 \\
\hline Income change (net monthly) & -0.0338 & 0.1687 & $\mathbf{- 0 . 7 8 9 9}$ \\
\hline Number of job position changes & 0.1022 & $\mathbf{0 . 6 0 2 1}$ & -0.1393 \\
\hline Number of promotions & 0.2348 & 0.0391 & -0.193 \\
\hline Net monthly income & -0.0483 & -0.176 & 0.0329 \\
\hline Satisfaction with income & $\mathbf{0 . 4 8 5 0}$ & 0.2334 & -0.0350 \\
\hline Satisfaction with degree to which work involves interests & $\mathbf{0 . 6 6 0 3}$ & 0.2372 & 0.2371 \\
\hline Satisfaction with co-workers & $\mathbf{0 . 6 6 2 2}$ & -0.2802 & -0.1332 \\
\hline Satisfaction with use of skills and abilities & $\mathbf{0 . 5 5 5 6}$ & 0.4336 & 0.5022 \\
\hline Satisfaction with supervision & $\mathbf{0 . 7 5 3 5}$ & -0.1056 & 0.0554 \\
\hline Satisfaction with respect that others give to job & $\mathbf{0 . 6 8 7 0}$ & 0.2815 & 0.3574 \\
\hline Satisfaction with ability to develop ideas on job & $\mathbf{0 . 8 2 6 0}$ & 0.0160 & 0.0024 \\
\hline Satisfaction with job security & $\mathbf{0 . 6 6 5 9}$ & 0.1038 & -0.3725 \\
\hline
\end{tabular}

Source: Authors' survey

Table 1: Factor analysis results for career success. 
2004; Arthur et al., 1999) career transitions are moving in different directions with the exception of downward transitions, according to Baruch (2006) and Chudzikowski (2012). Results show that the criteria of promotion and career success are insignificant. In this sample more importance is given to the criterion of number of changes in employment. Thus, this indicates a shift from criteria related to the traditional career (promotion) to criteria related to the present career concept based on the number of job position changes. The results might be influenced by the direction of focus of the target sample, because a part of the research sample participated in promotion as a career transition.

\section{Impact of company size on extrinsic career success}

The results of the survey confirm that increase in the size of an organization leads to an increase in the number of employees who achieve a higher salary. With respect to change in income; the employees of micro companies and small companies have a similar income to that in their previous position. Medium sized company employees receive an income higher than in their previous position (corresponding to an increase of 200 - 400 EUR). Employees in large companies receive an increase in their income of less than 5000 CZK (EUR 200). However, with the increase in the company's size, the individual income grows more. In micro companies most of the respondents have had no change in income $(37.5 \%)$ or they have had an income change of less than $5000 \mathrm{CZK}$ per month $(21.87 \%)$. In small companies in category 3 (i.e. over 5001 up to $10000 \mathrm{CZK}$ ) the number of respondents fluctuated in all categories between $27-29.8 \%$ for every category (1, 2, and also 3). The same situation can be observed in medium sized companies where the proportions of respondents fluctuate from $26.5-32.4 \%$. Category 4 is the most highly represented in large companies, where the rise in income is more than $10001 \mathrm{CZK}$. In summary, with increased size of company there is an increase in the number of employees who achieve a higher salary.

\section{Impact of company size on intrinsic career success}

Average values of career success according to size of company illustrate the impact of company size on individual factors and career success determinants. Average values in each given category are shown in the Table 2.

After data analysis of absolute values the authors conclude that in medium sized and larger companies, the bigger the company is, the less were individuals satisfied with the respect expressed towards them. $25-30 \%$ of respondents chose a neutral midpoint position (on the Likert scale). This is related to the fact that in small companies the number of jobs is limited so there are one or two individuals in higher specialist-posts, while in larger companies there are several individuals in similar positions ( $\mathrm{Ng}$ et al., 2005). It is assumed that in small companies power is concentrated in the top management within the organizational structure and this may be the reason for employees to feel relatively well respected in comparison with larger companies, where power is distributed on lower levels (Baruch, 2006).

It is connected to the satisfaction with the job security criterion that a given position offers. The employees of middle sized and large companies were the least satisfied with it. Large company employers usually provide well prepared succession plans and have more jobs. Therefore, an employee has a better chance of transfer to another position (Baruch, 2004). On the other hand, large companies employ more employees. Thus there are more opportunities for substitution (employee replacement) in comparison with smaller companies. Increase in size of company leads to decrease in satisfaction with management style

\begin{tabular}{|c|c|c|c|c|c|c|}
\hline \multirow[b]{2}{*}{$\begin{array}{l}\text { Company size } \\
\text { (number } \\
\text { of employees) }\end{array}$} & \multicolumn{6}{|c|}{ I am satisfied with my position as regards } \\
\hline & $\begin{array}{c}\text { Level } \\
\text { of interest } \\
\text { stimulate }\end{array}$ & Co-workers & $\begin{array}{l}\text { Leadership } \\
\text { style }\end{array}$ & $\begin{array}{c}\text { Opportunities } \\
\text { to develop my } \\
\text { ideas }\end{array}$ & $\begin{array}{l}\text { Respect which } \\
\text { is expressed } \\
\text { to me }\end{array}$ & $\begin{array}{l}\text { Satisfaction } \\
\text { provided by } \\
\text { given position }\end{array}$ \\
\hline Up to 10 & 1.594 & 1.969 & 2.313 & 2.188 & 2.063 & 2.406 \\
\hline $11-50$ & 2.081 & 1.703 & 2.324 & 2.432 & 2.108 & 2.297 \\
\hline $51-250$ & 2.103 & 1.838 & 2.500 & 2.559 & 2.382 & 2.441 \\
\hline Up 251 & 2.236 & 1.989 & 2.742 & 2.742 & 2.449 & 2.461 \\
\hline
\end{tabular}

Source: Authors' survey 
as well as lower job interest. So in micro companies $90 \%$ of respondents were satisfied. Geoffroy (2001) adds that specialized positions are more broadly focused in small companies, while increase in company size may lead to more specialized job positions. Small company employees are the most satisfied with their co-workers. The survey shows that satisfaction with co-workers decreases with increase in company size. One of the reasons might be that with increase of number of employees there is a reduction in personal bonds. Respondents employed in micro companies answered neutrally, probably because where there are low numbers of employees they all know each other very well and prefer to give neutral answers, rather than admit that they are dissatisfied.

The next part of the research, after the factor analysis (which provided us basic understanding of the significant factors to career success) was to perform more advanced methods such as Simplex Lattice Design (SLD) by adding two information technology factors (C - IT competence, D - Rate of IT utilization) to the current design.

A class of response surface experiments that investigate products containing several components. It can be used a mixture design to study product characteristics associated with changes in the proportions of the components, process conditions, or the amount of mixture. The theory (Antony, 2003) provides three designs (simplex centroid, simplex lattice, and extreme vertices) and analyses three types of experiments:

- Mixture, where the response is assumed to only depend on the proportions of the components in the mixture. For example, paint colour only depends on the pigments used.

- Mixture-process variable, where the response is assumed to depend on the relative proportions of the components and the process variables, which are factors in an experiment that are not part of the mixture, but may affect the blending properties of the mixture. For example, the adhesive properties of a paint may depend on the temperature at which it is applied.

- Mixture-amount, where the response is assumed to depend on the proportions of the components and the amount of the mixture. For example, the amount applied and the proportions of the ingredients of a fertilizer may affect the growth of a house plant.
According to Kowalski (2011), the Simplex designs are used to study effects of mixture components on the response variables. A ( $p, m)$ simplex lattice design for $p$ components consists of points defined by the following coordinate settings: the proportions assumed by each component take $\mathrm{m}+1$ equally spaced values from 0 to 1 :

$x_{i}=0, \frac{1}{m}, \frac{2}{m}, \ldots ., 1 \quad \mathrm{i}=1,2, \ldots, \mathrm{p}$

And all possible combinations of the proportions from Equation (1) are used. As an example, let $\mathrm{p}=5$ and $\mathrm{m}=2$. Then:

$x_{i}=0, \frac{1}{2}, 1 \quad \mathrm{i}=1,2,3,4,5$

And the simplex lattice consists of the following twelve runs:

$$
\begin{aligned}
& \left(x_{1}, x_{2}, x_{3}, x_{4}, x_{5}\right)=(1,0,0,0,0),(0,1,0,0,0),(0,0,1,0,0),(0,0,0,1,0),(0,0,0,0,1), \\
& \left(\frac{1}{2}, \frac{1}{2}, 0,0,0\right),\left(\frac{1}{2}, 0, \frac{1}{2}, 0,0\right),\left(\frac{1}{2}, 0,0, \frac{1}{2}, 0\right),\left(\frac{1}{2}, 0,0,0, \frac{1}{2}\right) \\
& \left(0, \frac{1}{2}, \frac{1}{2}, 0,0\right),\left(0,0, \frac{1}{2}, \frac{1}{2}, 0\right),\left(0,0,0, \frac{1}{2}, \frac{1}{2}\right),\left(0, \frac{1}{2}, 0, \frac{1}{2}, 0\right) \\
& \left(0, \frac{1}{2}, 0,0, \frac{1}{2}\right),\left(0,0, \frac{1}{2}, 0, \frac{1}{2}\right)
\end{aligned}
$$

The next phase of the research is to perform more advanced methods such as response surface methodology (RSM) by adding center points and axial points to the current design.

In general (Antony, 2003), the number of points in a $(\mathrm{p}, \mathrm{m})$ simplex lattice design is:

$N=\frac{(p+m-1) !}{m !(p-1) !}$

\section{Mixture design}

Two additional factors - the level of competence of information technology $\mathrm{C}$ and degree of use of information technologies D - were used for the Lattice simplex design (see Table 3).

The results of the analysis are shown in Table 4. The calculated effect factor in the coded values (response factor to change from -1 to +1 ) is in the first column of Table 4. The second column presents the regression coefficient (that is a half effect of each factor).

The results of the analysis of variance are shown in Table 5. The first column presents Degrees of freedom (DF). The DF is the amount of information data provide that can be used to estimate the values of unknown population parameters. and calculate the variability of these estimates. The second very important indicator 


\begin{tabular}{|c|c|c|c|c|c|c|c|c|}
\hline StdOrder & RunOrder & PtType & Blocks & $\begin{array}{c}\text { A-occup. } \\
\text { status }\end{array}$ & $\begin{array}{c}\text { B-salary } \\
\text { increase }\end{array}$ & $\begin{array}{c}\text { C - IT } \\
\text { competence }\end{array}$ & $\begin{array}{c}\text { D - } \\
\text { Utilization } \\
\text { IT }\end{array}$ & $\begin{array}{c}\text { Yield - } \\
\text { Careersuccess }\end{array}$ \\
\hline 7 & 1 & 2 & 1 & 0.0 & 0.5 & 0.0 & 0.5 & 0.52 \\
\hline 6 & 2 & 2 & 1 & 0.0 & 0.5 & 0.5 & 0.0 & 0.41 \\
\hline 9 & 3 & 2 & 1 & 0.0 & 0.0 & 0.5 & 0.5 & 0.27 \\
\hline 4 & 4 & 2 & 1 & 0.5 & 0.0 & 0.0 & 0.5 & 0.73 \\
\hline 10 & 5 & 1 & 1 & 0.0 & 0.0 & 0.0 & 1.0 & 0.24 \\
\hline 1 & 6 & 1 & 1 & 1.0 & 0.0 & 0.0 & 0.0 & 0.39 \\
\hline 3 & 7 & 2 & 1 & 0.5 & 0.0 & 0.5 & 0.0 & 0.68 \\
\hline 5 & 8 & 1 & 1 & 0.0 & 1.0 & 0.0 & 0.0 & 0.30 \\
\hline 2 & 9 & 2 & 1 & 0.5 & 0.5 & 0.0 & 0.0 & 0.87 \\
\hline 8 & 10 & 1 & 1 & 0.0 & 0.0 & 1.0 & 0.0 & 0.11 \\
\hline
\end{tabular}

Source: own processing

Table 3: List of randomized process parameters for the Lattice simplex experiment.

\begin{tabular}{|c|c|c|c|c|c|}
\hline & & $\mathrm{SE}$ & & & \\
\hline Term & Coef & Coef & $\mathrm{T}$ & P & VIF \\
\hline A-occupational status & 0.3900 & * & * & * & 1.750 \\
\hline B-Salary increase & 0.3000 & * & * & * & 1.750 \\
\hline C - IT competence & 0.1100 & * & * & * & 1.750 \\
\hline D - Utilization rate of IT & 0.2400 & * & * & * & 1.750 \\
\hline $\begin{array}{l}\text { A-occupational status* } \\
\text { B-Salary increase }\end{array}$ & 2.1000 & * & * & * & 1.500 \\
\hline $\begin{array}{l}\text { A-occupational status* } \\
\text { C - IT competence }\end{array}$ & 1.7200 & * & * & * & 1.500 \\
\hline $\begin{array}{l}\text { A-occupational status* } \\
\text { D - Utilization rate of IT }\end{array}$ & 1.6600 & * & * & * & 1.500 \\
\hline B-Salary increase*C - IT competence & 0.8200 & * & * & * & 1.500 \\
\hline $\begin{array}{l}\text { B-Salary increase* } \\
\text { D - Utilization rate of IT }\end{array}$ & 1.0000 & * & * & * & 1.500 \\
\hline $\begin{array}{l}\text { C - IT competence* } \\
\text { D - Utilization rate of IT }\end{array}$ & 0.3800 & * & * & * & 1.500 \\
\hline
\end{tabular}

Source: own processing

Table 4: Lattice design for estimation of regression coefficients for Yield - Career success (component proportions).

\begin{tabular}{|c|c|c|c|c|c|c|}
\hline Source & $\mathrm{DF}$ & Seq SS & Adj & Adj MS & $\mathrm{F}$ & P \\
\hline Regression & 9 & 0.5324 & 0.5324 & 592 & & \\
\hline Linear & 3 & 0.198267 & 0.041400 & 0.013800 & * & * \\
\hline Quadratic & 6 & 0.334093 & 0.334093 & 0.055682 & * & * \\
\hline A-occupa*B-Salary & 1 & 0.093130 & 0.183750 & 0.183750 & * & * \\
\hline$A-o c c u p a{ }^{*} C-I T C$ & 1 & 0.082477 & 0.123267 & 0.123267 & * & * \\
\hline A-occupa ${ }^{\star} D$ - Util & 1 & 0.097896 & 0.114817 & 0.114817 & * & * \\
\hline B-Salary ${ }^{\star C}-$ IT C & 1 & 0.016973 & 0.028017 & 0.028017 & * & * \\
\hline B-Salary ${ }^{\star} \mathrm{D}-\mathrm{Util}$ & 1 & 0.037600 & 0.041667 & 0.041667 & * & * \\
\hline$C-I T C^{\star} D-U t i l$ & 1 & 0.006017 & 0.006017 & 0.006017 & * & * \\
\hline Residual Error & 0 & * & * & * & & \\
\hline Total & 9 & 0.532360 & & & & \\
\hline
\end{tabular}

Source: own processing

Table 5: Analysis of Variance for Yield - Career success (component proportions).

of regression model quality is shown in column two - Sum of squares (Seq SS). This indicator represents a measure of variation or deviation from the mean for individual interactions between factors of the regression model. It is calculated as a summation of the squares of the differences from the mean. The calculation of the total sum of squares considers both the sum of squares from the factors and from random chance or error.

The contour plots in Figure 1 and figure 2 show how a response variable (career success) relates 


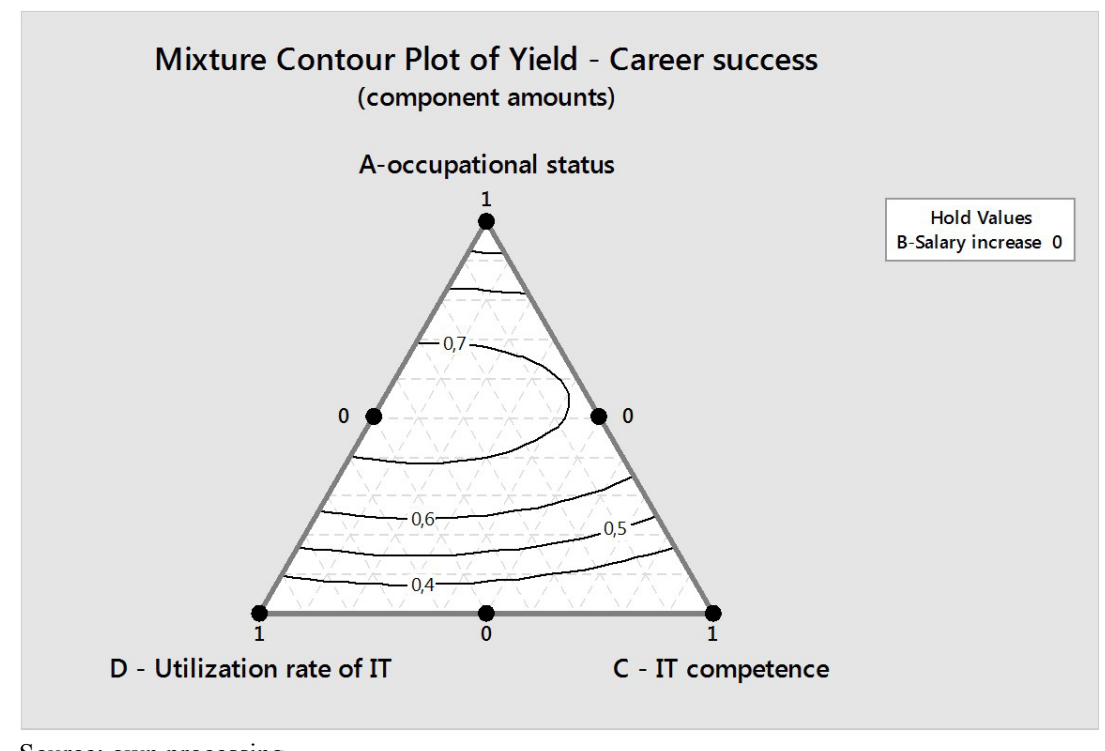

Source: own processing

Figure 1: Result of the simplex lattice design for career success depending on occupational status. IT utilization and IT competence.

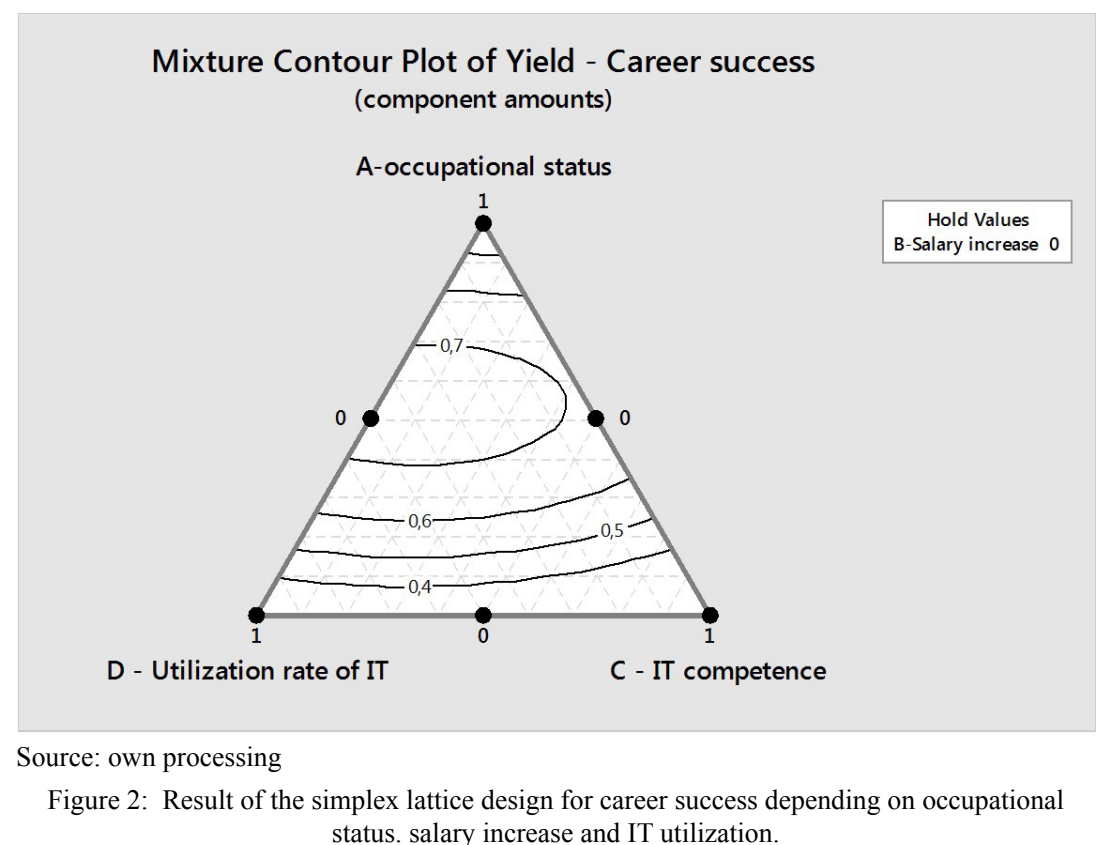

to three components (the percentage of components of the modified IT factors. which are A.C.D on Figure 1 and A.B.D on fig. based on a model equation. Points which exhibit the same response are connected to produce the contour lines of constant responses. Because a contour plot only shows three components at a time. whilst holding any other components and process variables at a constant level. contour plots are only valid for fixed levels of the extra variables. If the holding levels are changed. the response surface of the career success changes as well. sometimes drastically.

\section{Conclusion}

It is well established that career success is an important construct in career management (Arthur et al.. 1999). As the independence of an individual employee increases in a company there is a shift in significance from extrinsic factors to intrinsic factors relevant to career success. The validity of career success criteria was confirmed in this research sample. On the basis of factor analysis three factors were generated. where career satisfaction was the most significant. 
The results support the validity of present thinking on careers and confirm that a career can be multidirectional. Unless an employee is determined to climb the career ladder. As regards three career success factors the size of company was confirmed as having an impact on career success. The results show that as company size increases. so does the number of high earning employees. Employees of micro companies and small companies still achieve the same income after career transition.

It was statistically confirmed that there is a relationship between company size and the other six career satisfaction criteria (except income satisfaction). The growth of large companies leads either to a decrease in satisfaction or to no effect. In large companies. employees were the most satisfied with their co-workers and job interest. compared with smaller companies. On the basis of these results it is possible to recommend that companies develop specialization of their career programs according to company size.

From a methodological point of view. we recommend comparing multiple software tools to support decision-making and evaluation factors in career growth. Supporting IT tools used in the evaluation (Statistica 10 modules and t-test) and qualitative and quantitative analysis (software tools for decision-making tree of strategy career). although relatively simple. also solve the partial aspects (statistical calculations or relationship factor + hypothetical relevance factor $=>$ inclusion among the relevant factors $\Rightarrow$ extension of the structure of the questionnaire answering questions $\Rightarrow$ determination of the weights of factors $\Rightarrow$ career options structure relationships). Thus. software tools are either goal-directed used or are used for implementation of specific method(s) of calculation.

The optimum would be to strengthen research in this direction. so that the resulting methodology of career comparison could be suitable for selection or development of new purpose-built software with a reasonable compromise between simplicity. availability. coverage of all key needs methodological procedure. Appropriate form would be a gradual development of tools for the evaluation of these two concepts of career options in the form of cloud services - existing timeproven functionality in the software market could only be used as a plug-in and custom development will primarily focus on implementation of methodological framework. The application would then not be limited to factors such as company size. but all external factors involved in the methodology for which there is enough data. Suggested conclusions "Methodical process of developing a career system" elaborated on the basis of research in agribusinesses are useful in other sectors of the national economy.

While small companies and micro companies may not be able to offer higher income or financial rewards. they can offer more interesting tasks and broader job position specialization to their employees Schmidt (2011). It is recommended for micro and small companies to use intrinsic career success factors. Extrinsic career success factors are more appropriate for large companies. because they are more readily incorporated into formalized career programs and plans. Thus. it is recommended that large companies utilize extrinsic career success factors. which are related to formal career programs and career plans. At the same time they should put emphasis on multidirectional career moves and decentralize responsibility to the lower positions.

\section{Acknowledgements}

This article is a part of the research project of the Czech University of Life Sciences and has been made possible due to the support of the Internal Grant Agency (IGA) of the CULS Prague. Registration No. 20141018 - „Role podniku v přístupech kariérního plánování“ (Role of enterprise in approaches of career planning).

Corresponding author:

Doc. Ing. Tomáš Macák. Ph.D.

Department of Management, Faculty of Economics and Management

Czech University of Life Sciences Prague, Kamýcká 129, Prague 6, 165 21, Czech Republic

E-mail:macak@pef.czu.cz 
Doc. Ing. Jaromír Štůsek. CSc.

Department of Management, Faculty of Economics and Management

Czech University of Life Sciences Prague, Kamýcká 129, Prague 6, 165 21, Czech Republic

E-mail:stusek@pef.czu.cz

Ing. Kateřina Venclová

Department of Management, Faculty of Economics and Management

Czech University of Life Sciences Prague, Kamýcká 129, Prague 6, 165 21, Czech Republic

E-mail:venclovak@pef.czu.cz

\section{References}

[1] Mačiulyté-Šniukiené, A. Gaile-Sarkane, E. Impact of information and telecommunication technologies development on labour productivity. Procedia - Social and Behavioral Sciences. 2014, Vol. 110, p. 1271 - 1282. ISSN 1877-0428.

[2] Antony, J. Experimental Design of Experiments for Engineers and Managers using Simple Graphical Tools. Butterworth-Heinemann. Oxford. 2003. p. 190. ISBN 9780750647090.

[3] Arthur, M. B., Inkson, K., Pringle, J. K. The new careers: Individual action and economic change. London: Sage. 1999. p. 192. ISBN-10: 0761959327, ISBN-13: 978-0761959328

[4] Arthur, M. B., Khapova, S. N., Wilderom, C. P. M. Career success in a boundaryless career world. Journal of Organizational Behavior. 2005, Vol. 26, p. 177-202. ISSN 0001-8791.

[5] Arthur, M. B., Khapova, S. N., Wilderom, C. P. M. Career success in a boundary less career world. Journal of Organizational Behavior. 2005, Vol. 26, p. 177-202. ISSN 0001-8791.

[6] Baruch, Y. Transforming careers: from linear to multidirectional career paths. Organizational and individual perspectives. Career Development International. $9^{\text {th }}$ January 2004. p. 58-73. doi: 10.1108/13620430410518147. ISSN 1362-0436.

[7] Baruch, Y. Career Development in Organizations and Beyond: Balancing Traditional and Contemporary Viewpoints. Human Resource Management Review. 2006, Vol. 16, p. 125 - 138. ISSN 0958- 5192.

[8] Che,. Y. Chinese Knowledge Employees' Career Values. Perceived Organizational Support and Career Success. iBusinnes. 2011, Vol. 3, p. $274-282$.

[9] Colakoglu, S. N. The impact of career boundary lessness on subjective career success: The role of career competencies. career autonomy. and career insecurity. Journal of Vocational Behavior. 2011, Vol. 79, p. 47 - 59. ISSN 0001-8791.

[10] Chudzikowski, K. Career transitions and career success in the „new“ career area. Journal of Vocational Behavior. 2012, Vol. 81, p. 298 - 306. ISSN 0001-8791.

[11] Disman, M. Jak se vyrábí sociologická znalost. (How sociology knowledge is produced, in Czech), Prague: Karolinum. 2008. ISBN 978-80-246-0139-7.

[12] Dries, N. The meaning of career success: Avoiding reification through a closer inspection of historical. cultural and ideological contexts. Career Development International. 2012, Vol. 16, p. 364-384.

[13] Geffroy, E. K. Chci nahoru (I want up, in Czech). Prague: Management Press. 2001. $1^{\text {st }}$ ed., p. 188, ISBN 80-7261-057-0.

[14] Hebák, P., Hustopecký, J., Malá, I. Vícerozměrné statistické metody 3. (Multidimensional statistic methods, in Czech), Prague: Informatorium. 2006. ISBN 80-7333-036-9.

[15] Hendl, J. Kvalitativní výzkum. Základní teorie, metody a aplikace (Qualitative research. Basic theory, methods and applications, in Czech). Prague: Portál. s. r. o. 2006. ISBN 978-80-7367-485-4.

[16] Heslin, P. A. Conceptualizing and evaluating career success. Journal of Organizational Behavior. 2005, Vol. 26, p. 113-136. ISSN 0001-8791. 
[17] Judge, T. A., Cable, D. M., Boudreau, J. W., Bretzt, R. D. An empirical investigation of the predictors of executive career success. Personnel Psychology. 1995, Vol. 48, p. 485-519.

[18] Klupakova, H., Venclová, K. Impact of company size on the career success of employes. Journal of competitiveness. 2013. ISSN 1804-1728.

[19] Kvapil, K. Češi jsou loajálními zaměstnanci Czech are loyal emploees, in Czech) [Online] Available: http://www.novinky.cz/kariera/246487-cesi-jsou-loajalnimi-zamestnanci.html[Accessed: $22^{\text {nd }}$ December 2012].

[20] Ng, W. H., Eby, L. T., Sorensen, K. L., Feldmann, D. C. Predictors of Objective and Subjective Career Success, A meta-Analysis, Personnel Psychology. 2005, Vol 58, No. 2., p. 367-408. ISSN 1833-3850.

[21] Ng, E. S. W., Law, A. Keeping Up! Older Workers“ Adaptation in the Workplace after Age 55*, Canadian Journal on Aging-Revue Canadienne Du Vieillissement. 2014, Vol. 33, No. 1, p. 1-14. ISSN 0714-9808.

[22] Restubog, S., Bordia, P., Bordia, S. Investigating the role of psychological contract breach on career success: Convergent evidence from two longitudinal studies. Journal of Vocational Behavior. 2011, Vol. 79, No. 2., p. 428 - 437. ISSN 0001-8791.

[23] Saari, L. M., Judge, T. A. Employee attitudes and job satisfaction. Human Resource Management. 2004, Vol. 45, No. 3, p. 395 - 407. DOI: 10.1002.

[24] Seiber. S. E.. Krainer. M. L. Proactive Personality Indirectly Relates to Career Progression and Satisfaction through Specific Proactive Behaviors and Cognitive Process. Personnel Psychology. 2011, Vol, 54, p. $845-874$.

[25] Štůsek J. Modely strategického myšlení v agribusinessu. Lanškroun. TG TISK s.r.o. 2008. p. 144. ISBN 978-80-903680-8-8.

[26] Verbruggen, M. Psychological mobility and career success in the 'new' career climate. Journal of Vocational Behavior. 2012, Vol. 81, No. 2, p. 289 - 297. ISSN 0001-8791. 